\title{
"This may appear unmanly Tenderness". Homosocial Bonds and (Un)ruly Women in George Granville's The Jew of Venice (1701)
}

\author{
Lisanna Calvi
}

\begin{abstract}
In 1701 George Granville produced an adaptation of Shakespeare's The Merchant of Venice, which he renamed The Jew of Venice. In the preface, Granville declared he was operating in the wake of the "great men" who, before him, fitted Shakespeare's works for the Restoration stage and indeed the simplification of his plot and excision of a few characters seem to follow this lead. Although one may expect the new play to revolve mainly around Shylock, the Jew becomes little more than a (doubtfully) comic appendix, while Bassanio's role and his relationship with Antonio, now characterised by overt loving feelings, receive Granville's closest attention. This, however, seems to go against the play's Prologue in which Dryden's ghost laments the endorsement of open homosexuality on the contemporary stage, apparently cleansing both Granville's and Shakespeare's plays from this 'accusation'. Unexpectedly enough, though, the Jew of Venice is remarkably rich in allusions to the two friends' (homosexual) bonding which eventually leads to the exclusion of women and the silencing of their 'unruliness'. This raises a few questions: was Granville exploring the topic of male-male ties by camouflaging the operation under a misleading title? How does this operation fit into a dawning new mode of Shakespearian adaptations? And how did The Jew of Venice respond to contemporary social and cultural trends, also with regard to women's social role and position?
\end{abstract}

\section{Keywords}

Granville, The Jew of Venice, unruly women, homosocial, Shakespeare 
As Claude Lévi-Strauss famously observed with regard to the archaic dynamics of marriage,

The total relationship of exchange which constitutes marriage is not established between a man and a woman, where each owes and receives something, but between two groups of men, and the woman figures only as one of the objects in the exchange, not as one of the partners between whom the exchange takes place. (LÉVI-STRAUSS 1969: 115)

In Shakespeare's The Merchant of Venice Portia is the object in the exchange prescribed by her father's will. Later on, by setting into motion the 'pound of flesh' plot, she validates Antonio's and Bassanio's relationship as a "homosocial bond, a continuum of male relations which the exchange of women entails" (NEWMAN 1987: 22). Yet, and perhaps unsurprisingly so, Portia bypasses this logic of 'econo-sexual' exchange, transgresses the traditional norms of feminine conduct - one made of obedience and silence - and establishes herself as an "unruly woman", one who "steps outside her role and function [...] a woman who dresses like a man, who embarks upon behavior ill-suited to her 'weaker' intellect, a woman who argues the law" (28).

After 1605 - which marks the last known performance of The Merchant of Venice (SHAKESPEARE 2010: 113) - Portia's "unruliness", along with the play itself, roused no more interest in the theatre for almost a century when it reappeared in a revised and newly titled version by George Granville, Lord Lansdowne. The Jew of Venice, as it was renamed, was performed at Lincoln's Inn Fields by Betterton's troupe, probably in the first part of 1701 (SPENCER 1965: 29). Thomas Betterton himself took the part of Bassanio whose role was fattened probably in order to meet the great actor's expectations for a larger presence on stage. The play was successful and replaced Shakespeare's original at least until Charles Macklin - the 'Jew that Shakespeare drew' - restored The Merchant of Venice in 1741.

With regard to Granville's new drama, critical attention has concentrated mainly on Shylock's new title-role (WILSON 1943; CRAFT 1987; SCHNEIDER 1993 ; see also ZACCHI 1994), while the play has been generally categorised as sheer comedy. This, in fact, only partially corresponds to its dramatic deployment which, rather than on the Jew, focuses on the relationship between Antonio and Bassanio. To the discussion of the two men's (ambiguous) bonding and to Portia's role in it I will devote the following pages.

In his "Advertisement to the Reader" Granville alludes to The Merchant of Venice's original weakness by locating it in its "Foundation [...] being liable to some Objections" (GRANVILLE 1965: 347, 1l. 1-2); nevertheless, he also observes, Shakespeare's work is rich in "so many Manly and Moral Graces in the Characters and Sentiments, that [... the reader] may excuse the Story, for the sake of the Ornamental Parts" (1l. 4-6). These remarks endow the adaptation with a slightly different conceptual design from what the usual Restoration 'make fit' strategy has taught us. Restoration adaptors normally claimed that their work consisted in the refining of raw, if precious, material and their alterations often proved outrageous and went far beyond the rearrangement of the 
plots or the addition of a few scenes. Granville interestingly places himself in the wake of the great Restoration playwrights, "Great Men who have employ'd their Endeavours the same Way" (1l. 7-8), but his attitude is somehow reverential and more respectful to Shakespeare's work, a disposition which apparently anticipates later issues of Bardolatry. Unlike his predecessors, he took pains to mark the lines he added by placing them within inverted commas so that, he writes, "nothing may be imputed to Shakespear which may seem unworthy of him" (11. 15-16). ${ }^{1}$

Much as he was filled with admiration for Shakespeare, though, Granville did alter the original drama. His greatest care was, as he points out, to provide it with a less improbable plot by, for example, eliminating the (too many) scene changes between Venice and Belmont, excising the two Gobbos, and generally making his work conform to the unities of time, place, and action. ${ }^{2}$ The title was changed and the title role was given to Thomas Doggett, a favourite of William Congreve and well-known for his comic talent. This choice could suffice to label the Jew's presence in the adaptation as decidedly comic and indeed the character was given a few additional cues that tailored the part as prosaically humorous, rather than problematically revengeful as Shakespeare had characterised it. When asked for the three thousand ducats, Shylock sets the forfeiture of Antonio's loan at a pound of flesh and yet its terms are presented in a wittier and, if forcibly, more laughable fashion than what happens in The Merchant of Venice:

If you repay me not on such a day, in such a Place,

Such Sum or Sums as are exprest - Be this

The Forfeiture.

'Let me see, What think you of your Nose,

Or of an Eye - or of ... a Pound of Flesh

To be cut off, and taken from what Part

Of your Body - I shall think fit to name.

'Thou art too Portly, Christian!

'Too much pamper'd - (The Jew of Venice, 1.3.123-132) ${ }^{3}$

1 The procedure of marking differently Shakespeare's lines was also followed by William Burnaby in his unsuccessful 1703 adaptation of Twelfth Night, Love Betray'd; or the Agreeable Disapointment, even though Burnaby "mark'd with Inverted commas" (BURNABY 1931: 345) the original text and not his own (on Burnaby's play see MURRAY 2012). Granville was probably inspired by Colley Cibber who, in the 1700 printed edition of his Richard III, "caus'd those [lines] that are intirely Shakespear's to be Printed in this Italick Character; and those lines with this mark (') before 'em, are generally his thoughts, in the best dress I could afford 'em: What is not so mark'd, or in a different Character is intirely my own" (CIBBER 1965: 279; see also DAVIDSON 2012: 196-198). Also, unlike other adaptors who, as Michael Dobson justly foregrounds, "modernized Shakespeare's language in order to make it blend in with their own [... Granville] alters his own diction to imitate that of Shakespeare" (DOBSON 1992: 123-124).

2 For a detailed analysis of Granville's alterations, see (CRAFT 1987).

3 For a clearer attribution of authorship, I maintained Granville's original use of inverted commas in the quotations. 
Another instance of the Jew's flippancy is included in an extra scene in 2.2 when Antonio, Shylock, Gratiano and, of course, Bassanio gather at Bassanio's house for dinner and are about to enjoy a musical entertainment, a masque of Peleus and Thetis. ${ }^{4}$ Before the spectacle starts, everybody toast to what they appreciate most in life, and Shylock mentions his love for 'breeding' money:

'I have a Mistress, that out-shines 'em all -

'Commanding yours - and yours tho' the whole Sex:

'O may her Charms increase and multiply;

'My Money is my Mistress! Here's to

'Interest upon Interest.

[Drinks.

(The Jew of Venice, 2.2.27-31)

These words portray the Jew as obscenely greedy and seems to respond to a different stereotype from the one coming from the medieval blood libel tradition from which Shakespeare drew. Granville's Shylock is a "Stock-jobbing Jew", as the Prologue (1. 29) defines him, that is, a 'modern', eighteenth-century version of the old Shakespearean loan shark. Ancestors of modern brokers, stock jobbers were generally looked at unfavourably as corrupt and unscrupulous individuals and were indeed instrumental in helping create the infamous South Sea Bubble in $1720 .^{5}$ This stock jobber Shylock, however, is commonly tolerated by the Christians in the play - he and Antonio even shake hands in order to seal the bond - as a coarse, ludicrous, but financially necessary, presence, a trait we may find in Shakespeare too but to which Granville gives much more prominence.

We do not know whether this version of Shylock provoked the audience's laughter, even if this may have been the case if we take heed of Nicholas Rowe's comment on The Merchant of Venice, included in his 1709 edition of the Bard's works: "tho' we have seen that Play Receiv'd and Acted as a Comedy, and the Part of the Jew perform'd by an Excellent Comedian, yet I cannot but think it was designed Tragically by the Author" (ROWE 1709: xix-xx).

The Jew in The Jew of Venice, however, cannot be defined as an authentically comic presence, not only because he retains some of the traits of his former unforgiving temper, but mainly because he transforms into a morally repulsive rather than jesting character. In the trial scene, for example, he sounds offensively excessive when voicing his desire for revenge. When Bassanio volunteers to give a pound of flesh in place of Antonio, Shylock retorts by pointing out how useless his sacrifice would be. Bassanio - he grins - will surely commit suicide after Antonio's death out of guilt for being the cause

4 Granville "puts into practice the project devised by young Gratiano and Lorenzo who, in the Shakespearean play (2.4), plan to organise a masque but cannot realise it because Antonio announces that the wind is favourable for Bassanio to set off" (INNOCENTI 2010: 51; my translation).

5 Daniel Defoe attacked stock jobbers in his pamphlet The Villainy of Stock-Jobbers Detected, coincidentally published in 1701. In it he defines this investment strategy and its advocates as a "destructive Hydra" and a "new Corporation of Hell" respectively (DEFOE 1701: 9). 
of his friend's death, “[a]nd so my ends are serv'd on both" (4.1.208). This amplification of cruelty is gratuitous and rings superficially cheap rather than embedded into some long-standing religious and ethnic hatred. Again, his reaction to Portia's "drop of Christian blood" (4.1.226) quiddity is a trivial "Humph" (1. 228), whose inarticulateness gestures towards his shallowness and moral laxity. It does not come as a surprise then that this Shylock will not be forced to convert to Christianity as if he were not dignified enough to undergo such a downfall; as Catherine Craft put it, "he is not of the stature to find that [conversion] a humiliating punishment" (CRAFT 1987: 45) ${ }^{6}$

The play's title is therefore rather misleading since the main character is not Shylock, reduced to a vulgarly mean wheeler-dealer, but rather Bassanio. As mentioned above, his role was perceptibly enlarged primarily in order to meet Thomas Betterton's actorly skills but probably also in order to transform his and Antonio's relationship into the play's governing feature. This partly reprises the popular Restoration theme of male friendship - a topic inherited from Caroline drama - but also looks at both the continuance of patriarchy and the maintenance of its standards as well as the subsequent renegotiation of the position of women.

In The Jew of Venice Bassanio is given a number of additional lines which often point at the celebration of his friendship with Antonio. ${ }^{7}$ But what kind of friendship is this? In 1.1, Antonio characterises it as decidedly masculine by comparing it to a more female-like bashful attitude:

'Is this to be a Friend? With blushing Cheek,

'With down-cast Eyes, and with a faltring Tongue,

'We sue to those we doubt: Friendship is plain,

'Artless, familiar, confident and free. (1.1.66-69)

Accordingly, when Shylock is about to obtain his bloody collateral at the tribunal, Bassanio - in true heroic style - interposes and asks to be sacrificed instead of his friend. His readiness to die for Antonio brings the celebration of ideal (male) friendship to its utmost level. At the banquet in 2.2, however, their friendship was toasted to as "immortal" and made equal to a matrimonial knot:

Antonio. 'This to immortal Friendship; fill it up -

'Be thou to me, and I to my Bassanio,

'Like Venice and her Adriatick Bride,

'For ever link'd in Love.

Bassanio. 'Thou joyn'st us well: And rightly hast compar'd;

'Like Venice on a Rock, my Friendship stands

'Constant and fix'd; but 'tis a barren Spot;

6 On this see also (INNOCENTI 2010: 91), who suggests an interestingly different reading of the finale attuned to the interpretation of Shylock's role as a comic one.

7 The words 'friend(s)' and 'friendship' appear fifty-nine times in the play. Antonio refers to Bassanio as his "friend" fifteen times, and so does Bassanio, who often qualifies the merchant as "my lov'd friend" (2.2.65), "the best of Friends" (3.1.26), "my best friend" (3.1.257, 5.1.126), "the dearest friend to me" (3.1.265). 


'Whilst like the liberal Adriatick, thou
'With Plenty bath'st my Shoars -
'My Fortunes are the Bounty of my Friends.
Antonio. 'My Friend's the noble Bounty of my Fortune.
'Sound every Instrument of Musick there,
'To our immortal Friendship.
(2.2.1-13)

The emphasis is put on the liberality, in money and in love, that Antonio has just shown towards Bassanio, whose companionship he praises above any fortune or gain. Tellingly, this ideal clashes with Shylock's. The Jew is also asked to propose a toast and - true to his 'nature' - drinks to his "Mistress" money and to her prodigious capacity to procreate. His words resound of low comedy humour but also allude to a different type of abnormality, which identifies "capitalism itself as a form of sexual perversion" and "presents Shylock as a fetishistic precursor of Auric Goldfinger who [...] toasts the sole object of his desire" (DOBSON 1992: 123). Antonio's and Bassanio's toast, however, is not exempt from sexual allusions. The reference to Bassanio as a (same-sex) bride and his later hint at his friendship's power to 'stand' rock-like make the two men's relationship ambiguous enough. Still operating within the metaphorical image of Venice and the sea, the two men describe their interaction as sexual: Bassanio, now entirely feminised, laments his barrenness until Antonio "with Plenty" washes his "Shoars" and impregnates him (with "Fortunes"). Later on, upon his departure for Belmont, Bassanio is loath to leave his friend and thus lingers at the pier:

Servant. 'The Master of the Ship has sent agen.

Bassanio. 'One more Embrace: To those who know not Friendship

'This may appear unmanly Tenderness;

'But 'tis the frailty of the bravest Minds.

Antonio. 'I ask but this, Bassanio;

'Give not your Heart so far away,

'As to forget your Friend.

'Come, is all ready? I must hasten you.

Gratiano. 'If you were ready to part,

"Tis all we stay for now.

Bassanio. '...Oh my Antonio! 'tis hard, tho' for a Moment, 'To lose the Sight of what we Love.

Shylock. aside.] 'These two Christian Fools put me in mind

'Of my Money: just so loath am I to part with that.

Bassanio. 'Gratiano, lead the way: Shylock once more farewell.

'We must not part, but at the Ship, Antonio:

'Lovers and Friends, should they for Ages stay,

'Would still find something left, that they would say. [Exeunt.

$(2.2 .89-110)$ 
Bassanio's reluctance is humorously remarked by Gratiano, who stresses how everybody is waiting only for the two men to stop goodbying, as it were, and by Shylock - strangely present here - who likens their relationship to the one he entertains with his money. And money, as we know, is his "Mistress", which makes of Antonio Bassanio's lover, rather than his friend, while Bassanio associates "Lovers and Friends" by relying on the cliché of lovers' never ending adieus. In his turn Antonio, in a true inamorato's fashion, begs him not to give his heart away as Bassanio promptly styles his "frailty" as "unmanly" still longing for one last embrace. Moments before, relying on the topos of the alba, or lovers' parting at dawn, he lamented how painful this separation is to him and even expanded on the same motif by alluding to sleep as an additional separating element between he and his "lov'd Friend":

\footnotetext{
'Oh my lov'd Friend! till now I never knew

'The pangs of parting Friendship.

'At distance I have tasted of the Pain,

'When the rude Morn has sunder'd us away,

'To our Repose: But, by my Soul, I swear

'Even then my Eyes would drop a silent Tear,

'Repugnant still to close, and shut out Thee.

$(2.2 .65-71)$
}

The image of repose evokes the idea of a night spent together which undoubtedly coats their relationship with a homosexual veneer. In the same way, when he volunteers to die for Antonio, Bassanio does so by giving his own body in place of his friend's, wishing to be physically abused for his sake. The concrete image of the body, and supposedly of the naked body, is thus exposed and offered not only to Shylock's cruelty but also to Antonio's gaze:

'Here stand I for my Friend. Body for Body,

'To endure the Torture: But one pound of Flesh

'Is due from him: Take every peice of mine,

'And tear it off with Pincers: whatever way

'Invention can contrive to torture Man,

'Practice on me: Let but my Friend go safe,

'Thy Cruelty is limited on him;

'Unbounded let it loose on me

(4.1.192-199)

At the Jew's sneering refusal, Bassanio throws himself towards his friend in order to physically protect him: 
Bassanio. 'Then thus I interpose.

[Draws and stands before Antonio: The Jew starts back. Antonio interposes.

Antonio. 'Forbear Bassanio, this is certain Death

'To both.

Bassanio. 'In one, both dye: since it must be,

'No matter how.

(4.1.210-213)

Antonio also intervenes and the performative dimension suggested here hints at a physical contact between the two men as Bassanio wishes they "dye" together.

The sexualisation of male bonding was indeed rather common in Restoration drama. As George E. Haggerty discusses in his Men in Love, "Restoration theater" should be "considered as a site of male-male desire" (HAGGERTY 1999: 23-24). Bringing examples from Dryden and Lee among the others, Haggerty, with special regard to Antonio and Dolabella in All for Love, identifies the presence on stage of sexualised male relations as an element that "helps to define the heroic" (23). "It is almost as if Dryden", he argues, "felt that his age was another that could condone erotic friendships between men, at least when they were articulated in the service of heroic cultural goals" (29). ${ }^{8}$ This reading appears to be very well attuned with The Jew of Venice too. The love between Antonio and Bassanio, which the two men have been alluding at and celebrating all along, paves the way for the larger-than-life, heroic readiness to die for each other in 4.1. Unsurprisingly enough, this critical perspective takes us back to the play's Prologue which alludes exactly to this problematic issue. Attributed to Granville's kinsman Bevil Higgons, the Prologue consists of an imaginary dialogue between the ghosts of Shakespeare and Dryden in which the former Laureate laments the endorsement of open homosexuality on the contemporary stage:

Dryden. Thro' Perspectives revers'd they Nature view,

Which give the Passions Images, not true.

Strephon for Strephon sighs; and Sapho dies,

Shot to the Soul by brighter Sapho's Eyes:

No Wonder then their wand'ring Passions roam,

And feel not Nature, whom th'have overcome.

For shame let genial Love prevail agen,

Your Beaux Love Ladies, and you Ladies Men.

Shakespeare. These Crimes unknown, in our less polisht Age,

Now seem above Correction of the Stage;

(Prologue, 1l. 18-27)

8 See also (HAGGERTY 2003) and David Halperin's response to Haggerty's criticism on this topic in (HALPERIN 2003). 
On the one hand, Dryden's complaint denies the presence of any such allusions in The Merchant of Venice and, on the other, it similarly 'absolves' Granville's play from the 'accusation' of portraying this kind of fondness. Why then would Granville expand Bassanio's role by including so many passages which in fact allude to the homoerotic/ homosexual nature of the relationship between the two men? Was the Prologue added in order to disperse any criticism in this regard? As Michael Dobson remarked, the Prologue voices "a crusade against [...] low comedy" and all that debases "real literature [...] beyond which all is grotesquerie, Frenchness, the fair, the masquerade, the unnatural, the inverted" (DOBSON 1992: 122-123). Be that as it may, this apologetic introduction certainly arouses our suspicion and allows us to read Antonio and Bassanio's friendship as a case of "unmanly tenderness" (2.2.91). This is seemingly confirmed, once more, in the trial scene. Right after the 'I'll-die-for-you' exchange, it is the Duke who intervenes in order to stop Bassanio. He does so in his capacity as judge and head of state, that is, the representative of (male) public authority and power: "'Before our Face this Insolence! And in a Court | Of Justice. Disarm and seize him [Bassanio]" (4.1.214-215). At his words Portia - here significantly disguised as a man - declares she has "a way to tame him [Bassanio]" (1. 216). Masculine state authority interposes in order to hush what we may term a public display of homosexual love that risks infringing social propriety, while the sexually ambiguous figure of a woman performing a male role declares to possess a way to bring the situation back to a more suitable and socially acceptable condition. But is this really only a question of decorum? With reference to Dryden's All for Love, Haggerty observes how "the politics of male-male desire [...] are as crucial to the emerging hegemony as are details of global conquest or female subjugation" (HAGGERTY 1999: 31). As The Merchant of Venice's hypertext, Granville's play is also permeated with commercial values and Antonio's and Bassanio's male-male bond is actually functional to the establishment of a masculinist economic and financial system.

As Haggerty underlined in his reading of George Lillo's The London Merchant (1731), the relationship between the two mercantile apprentices, Barnwell and Trueman, is characterised as decidedly, if subtly, homoerotic and represents in the play "a fully interpellated version of capitalist friendship" in that "male-male desire is [...] in the service [...] of capitalist economy" (HAGGERTY 1999: 43). This resounds of what Joseph Addison exemplified in his famous Spectator essay on the Royal Exchange. Addison celebrated London's mercantile cosmopolitanism ingraining itself in the lively and indispensable activity of merchants: "there are no more useful Members in a Commonwealth than Merchants. They knit Mankind together in a mutual Intercourse of good Offices" (ADDISON 2005: 63). The homosocial capitalist fabric these men "knit" is fundamental for the advancement, well-being, and economic progress of the community and of the nation, and this idea of sociability, ethically sound in that it brings about cooperation and reciprocal assistance, could never be degraded to mere economic egotism, which is represented in the play by Shylock's "Interest upon interest" attitude. The Jew's greed for money, or better, for an obsessive and economically barren accumulation of riches acts as a foil to Antonio's and Bassanio's "mutual Intercourse 
of good Offices". In Granville's play this collaborative mechanics is foregrounded by bringing about a fresh contraposition between the merchant and the "stock-jobbing" Jew, only flimsily based upon religious and racial difference and rather exclusively centred upon a conflicting economic outlook, as well as a revised interpretation of Antonio's and Bassanio's relation - which Shakespeare already presented as homoerotic, albeit in a more nuanced and problematic way - in terms of (homo)sociality. ${ }^{9}$ While The Merchant of Venice dramatises "the failure of male friendship in a radically shifting mercantile economy - an economy that seems better regulated by a social structure based on marital alliance and heterosexual reproduction" (PATTERSON 1999: 10), in Granville's play, this form of male bonding apparently excludes feminine agency. It is therefore interesting to look more closely at the figure of Portia, with special regard to act 5 when all characters, except for Shylock, reunite in Belmont.

In Shakespeare's play, Belmont represents what Northrop Frye calls

the green world [of] innocence and romance [which] takes the form of Portia's mysterious house [...] with its magic caskets and the wonderful cosmological harmonies that proceed from it in the fifth act. (FRYE 1957: 182-183)

This covers Lorenzo's speech at 5.1.70ff. which pivots on the Pythagorean analogy between the harmony of music and inner personal concord and peace. ${ }^{10}$ In The Jew of Venice, Jessica's and Lorenzo's long exchange is severely curtailed, ${ }^{11}$ while the allusion to music and harmony is moved to 2.2 and given to Bassanio. Moments before the masque begins, it is he and Antonio who speak Lorenzo's and Jessica's lines (2.2.3556), which once again qualifies them as lovers but also blesses their Venetian union with the commendation of spiritual (and physical) harmony. In The Merchant of Venice, the final comic resolution, which brings forth the restoration of a "proper and desirable state of affairs" (FRYE 1957: 164), is set in Belmont as opposed to Venice, the seat of ruthless trade and bloody bonds. By moving Lorenzo's speech to Venice (and assigning it to Bassanio), Granville's adaptation implies that ideal concord already inhabited Venice, Bassanio's house, and his relationship with Antonio too. Indeed, Bassanio's joy cannot be complete without his friend, a feature already present in Shakespeare but very much emphasised in Granville. In 3.1, after the lead casket has been opened, Nerissa calls for a (meta)theatrical closure:

9 As is well-known, the nature of Antonio's and Bassanio's relationship in The Merchant of Venice has been widely - and often lengthily - debated. "Whether Antonio's love", Alan Sinfield remarked, "is what we call sexual is a question which [...] is hard to frame, let alone answer" (SINFIELD 1996: 125).

10 "The man that hath no music in himself, | Nor is not moved with concord of sweet sounds, | Is fit for treasons, stratagems and spoils" (The Merchant of Venice, 5.1.83-85).

11 Granville maintains some 15 lines from Shakespeare's play in which the whole exchange occupies 57 lines, excluding the Messenger's and the Clown's interventions. 
'Methinks this looks like the last Act of a Play.

'All Parties are agreed; there remains nothing but

'To draw the Curtain, and put out the Lights.

(3.1.209-211)

At her suggestion, Gratiano immediately prompts the (heterosexual) celebration of this finale 'behind the scenes': 'A good hint my Love', he says, 'Let you and I make our Exit | About the same last Act, as you call it' (1l. 212-13). Bassanio unsurprisingly 'interrupts' his comrade's amorous plans and begs him to send a messenger to Antonio in order to "inform him of our Fortunes" (1. 219). By conquering Portia not only has Bassanio earned a rich patrimony and financial independence, but is also able to (re) enter with restored means the relationship with his friend. As Antonio told him earlier: "'In Friendship, who receives, | 'Obliges, by Acceptance, him that gives" (1.1.90-91) thus setting into motion a circularity from which, as we will see, Portia is virtually excluded. In the Shakespearean final double (triple) wedding feast, the merchant famously plays the 'odd man out' as "it becomes necessary to renegotiate Antonio's place in Portia's and Bassanio's relationship" with Antonio eventually becoming "the vehicle, both rhetorically and materially, of the couple's (re)bonding" (LANIER 2019: 149-150). Much differently from Shakespeare's Portia, who cuts short any courtesy in receiving Antonio at Belmont, in Granville she is well aware of the role Antonio plays in her husband's life and is willing to accept it, as long as she can partake into their relationship and become "a Third in friendship":

'I should behold him with a Jealous Eye,

'Who has so large a Share in my Lord's Heart.

To Antonio]

'Having his Leave, you'll not deny me yours,

'To make a third in Friendship: I doubly joy

'That you are safe and here.

$(5.1 .46-50)$

Antonio's role needs no renegotiation, and it is Portia who must gain inclusion into a male-male circle. Even the ensuing quarrel about the rings does not entail the redefinition of Antonio's function as the guarantor of Bassanio's marital fidelity, but has him realise he is "the unhappy subject of this Quarrel" (1. 155) which again bestows upon him a decidedly more active part into Bassanio's new household. It is Portia's position and role that needs to be renegotiated, or better, redirected towards 'normality'.

As noted above, the exchange of women sustains homosocial bonds and, as Karen Newman correctly observes, Bassanio reinforces this logic by giving his ring to Balthazar (NEWMAN 1987: 31). When Portia gives it back to her husband, the ring has accumulated "other meanings and associations" linked in primis to "female unruliness [and] deceptiveness" (31) which derive from the woman's earlier transgression in taking on a male role. In The Jew of Venice Portia still steps out of her role, takes the matter 
into her own hands, and behaves like a man among other men, yet her unruliness is very much softened. As soon as Bassanio has left for Venice and she has entrusted Lorenzo and Jessica with the "Husbandry and Conduct of [her] house" (3.1.306), she cuts things short by announcing that she has "some short Directions" (1. 322) for Nerissa and her servant, Balthazar. The rest of the scene is cut and so is the Shakespearean Portia's “cross-gender mockery" (LANIER 2019: 72), phallic puns included. ${ }^{12}$ Granville also eliminates the reference to Portia's new identity as Balthazar (the reading of Bellario's letter is excised) thus further soft-pedalling her 'masculinity'. Portia's new 'manly' status is likewise weakened by her passing allusion to her feminine sexuality when she declares that she possesses a "way to tame" (4.1.216) Bassanio's hot spirits. Also, when Nerissa follows Gratiano to Shylock's house with the intention to get her ring from him, she comments on how women may easily obtain whatever they wish from men: "'So many shapes have Women for Deceipt", she mordaciously observes, "That every Man's a Fool, when we think fit” (4.1.352-353). It is women's protean guilefulness then, and not their intellectual brilliancy that make them prevail over men. This partly erases their audacity and confines them back into a sexually determined role - and one should not forget that, unlike the Elizabethan tradition, Portia and Nerissa's roles were played by actresses so that the audience never lost sight of their actual sex.

Later on, when she finally reveals her disguise, which allowed her to enter the tribunal in act 4, Portia curiously refers to magic: "How quick an Operation is in Magick I "We have met already" (5.1.177-178). At this Bassanio violently reacts by accusing her of witchcraft and virtually imposes on her a construction of feminine monstrosity which entails social exclusion:

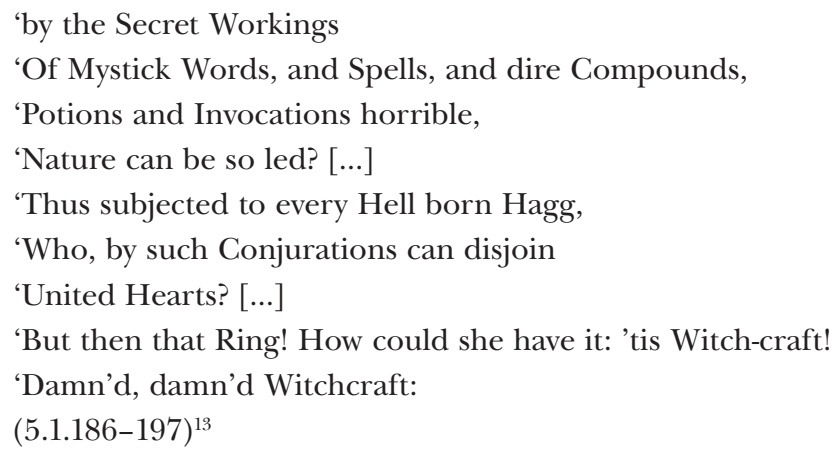

Feminine independence and self-determination as well as women's capacity to beat men at the game of logic and argumentation despite their 'weakness' appear to be unacceptable and the only way of coming to terms with such intellectual boldness is

12 For instance, "I'll [...] wear my dagger with the braver grace" (The Merchant of Venice, 3.4.64-65).

13 The "united hearts" he refers to are of course Portia's and his but he could very well be alluding to Antonio and himself since, in a fit of anger, he has just accused his friend of being the cause of the quarrel - which confirms, by the way, that they are fighting about the ring no more than they are fighting about Antonio. 
to ascribe it to magic, and even black magic. Portia is accused of being a hag, a female demon who brings imbalance and disorder into an otherwise perfectly harmonious (homosocial/sexual) relationship. Indeed, as argued by Eve Sedgwick in her 1987 study Between Men, "in any male-dominated society, there is a special relationship between male homosocial (including homosexual) desire and the structures for maintaining and transmitting patriarchal power" (SEDGWICK 1985: 25). Women, then, must be instructed not to invade such space and those who dare must be tamed back into order, secluded by and into the discourse of witchcraft in order to be later readmitted as subjugated objects. In Shakespeare, as soon as she realises that Bassanio has given away her ring Portia "equivocate[s] on husbandly domination, and female 'lightness" (JARDINE 1987: 13). The contractual breach, i.e. the disposal of the ring, brings forward sexual transgression: "I will become as liberal as you; | Will not deny him [Balthazar] anything I have, | No, not my body, nor my husband's bed” (The Merchant of Venice, 5.1.226-228). By virtue of that same ring, the "visual sign of her vow of love and submission to Bassanio" (NEWMAN 1987: 25), the woman actively regains dominion over herself, her body, even her riches.

The same does not happen in The Jew of Venice in which Portia transforms, in her own words, into the passive object/victim of the magic of the ring. It is not she who "[w]ill not deny him anything I have" as an act of willpower, but it is the ring itself, the symbol of female subjugation - and metonymic of female sex too - that guide her actions so that "nothing can deny the Man that has it" (5.1.133). The difference is enough to tell us how the new century could not abide the representation of strong-minded and independent women and their 'unruliness' had to be restrained and controlled. ${ }^{14}$ In fact, this parallels a dawning tendency in terms of women's rights, with special regard to property and inheritance. As Natalie Zemon Davis observes:

By the eighteenth century, married women in France and England had largely lost what independent legal personality they had formerly had, and they had less legal right to make decisions on their own about their dowries and possessions than at an earlier period. (ZEMON DAVIS 1975: 126)

This legal settlement was based upon the reinforcement of an essentially patriarchal code that validated men's privilege and superiority over women. This however, as Zemon Davis also underlines, "is not to say that females had no informal access to power or continuing vital role in the economy; but the character of those relations was in conflict" (ZEMON DAVIS 1975: 126). In fact, as Susan Staves argues, while "many women were relatively ignorant of the content of official law [...] others, who knew quite well what the code was, did not necessarily conform their conduct to it" (STAVES 1990: 25). Portia is well-aware of the code's substance and import as well as of the limitations it

14 This also anticipates a later tendency in Shakespearean adaptations which aimed at "making Shakespeare more decorous, more suitable to the refined taste of polite society" (MARSDEN 1995: 76) and entails here the transformation of Portia into an obedient and dutiful bride. The same import informs, for example, Benjamin Victor's 1762 adaptation of The Two Gentlemen of Verona (on this see CALVI 2020). 
imposes on her conduct. Her frailer legal rights (as a married woman, especially) are made explicit a couple of lines below, still with regard to the ring:

'Whoever has it, has the sure Command
'Of me, my Person, and of all that's mine:
'The dire Enchantment was so strongly wrought;
(5.1.136-138)

Others, she says, have "wrought" the magic of the ring, others have fashioned it as a token of subjugation which she cannot escape and by which she is spoken when calling male "Command" upon her. Nevertheless, she has amply demonstrated the vigour and potentially intimidating capacity of her agency, as the ever outspoken Gratiano underlines. In fact, her and Nerissa's "Art Magick" is endowed with an emasculating power:

Gratiano. 'You have so scar'd me with your Art Magick,

'That I shall scarce be a true Man these two Days;

(5.1.238-239)

Portia knows very well what the homosocial "code" of patriarchy is - "to transmit wealth from one generation of men to the next" (STAVES 1990: 4) - and adheres to it, even if tongue in cheek. If, on the one hand, she is aware of her limited scope, on the other, she is conscious of the latent disruptiveness of her power - and has not been afraid to use it. Ultimately, however, her action has been suitably ascribed to the unacceptable, if fascinating, practice of sorcery and her a-normativity has been tamed into obedience and passivity, thus making her 'acceptable' to eighteenth-century palates.

Granville himself foregrounded the ethical import of his adaptation by pointing out how it "[e]mbelish'd" Shakespeare's play "with good Morals and just Thought" (Epilogue, 1. 28). If Shylock is totally excluded from the final restoration of harmony not so much because of his religious difference but because of his financial depravity and (heterosexual) vulgarity, Portia can be accepted as a "third in Friendship" (5.1.49) only as long as she does not threaten a homosocially established system and accepts her role as the object in the exchange. Likewise, rather than being "unmanly", Bassanio's and Antonio's relationship reinforces masculine privilege and power, and erects a high(er) barrier against the many dangers of female 'unruliness'.

I am grateful to Theatralia's anonymous readers for their extremely valuable suggestions and thought-provoking comments. 


\section{Bibliography}

ADDISON, Joseph. 2005. The Spectator, no. 69, 1711. In Stephen H. Gregg (ed.). Empire Eं Identity. An Eighteenth-Century Sourcebook. Houndsmill, Basingstoke: Palgrave Macmillan, 2005, 60-63.

BURNABY, William. 1931. Love Betray'd or The Agreeable Disapointment. In Frederick E. Budd (ed.). The Dramatic Works of William Burnaby. London: The Scholartis Press, 1931, 343-403.

CALVI, Lisanna. 2020. Of Flowers and Weeds. Veering Towards Comedy in Benjamin Victor's Adaptation of The Two Gentlemen of Verona (1762). Il castello di Elsinore (2020): 82: 9-20.

CIBBER, Colley. 1965. The Tragical History of King Richard III. In Christopher Spencer (ed.). Five Restoration Adaptations of Shakespeare. Urbana: University of Illinois Press, 1965: 275-344.

CRAFT, Catherine A. 1987. Granville's 'Jew of Venice' and the Eighteenth-Century Stage. Restoration and Eighteenth Century Theatre Research 2 (1987): 2: 38-54.

DAVIDSON, Jenny. 2012. Shakespeare adaptation. In Fiona Ritchie and Peter Sabor (eds). Shakespeare in the Eighteenth Century. Cambridge: Cambridge University Press, 2012: 185-203.

DEFOE, Daniel. 1701. The Villainy of Stock-Jobbers Detected. London: n.p., 1701.

DOBSON, Michael. 1992. The Making of the National Poet. Shakespeare, Adaptation, and Authorship, 1660-1769. Oxford: Clarendon, 1992.

FRYE, Northrop. 1957. The Anatomy of Criticism. Princeton: Princeton University Press, 1957.

GRANVILLE, George. 1965. The Jew of Venice. In Christopher Spencer (ed.). Five Restoration Adaptations of Shakespeare. Urbana: University of Illinois Press, 1965: 345-402.

HAGGERTY, George E. 1999. Men in Love. Masculinity and Sexuality in the Eighteenth Century. New York: Columbia University Press, 1999.

HAGGERTY, George E. 2003. Male Love and Friendship in the Eighteenth Century. In Katherine O'Donnell and Michael O'Rourke (eds.). Love, Sex, Intimacy and Friendship between Men, 1550-1800. New York: Palgrave Macmillan, 2003: 70-81.

HALPERIN, David M. 2003. Introduction: Among Men - History, Sexuality, and the Return of Affect. In Katherine O'Donnell and Michael O'Rourke (eds.). Love, Sex, Intimacy and Friendship between Men, 1550-1800. New York: Palgrave Macmillan, 2003: 1-11.

JARDINE, Lisa. 1987. Cultural Confusion and Shakespeare's Learned Heroines: 'These are old paradoxes'. Shakespeare Quarterly 38 (1987) 1: 1-18.

INNOCENTI, Loretta. 2010. La scena trasformata. Adattamenti neoclassici di Shakespeare. Pisa: Pacini, 2010.

LANIER, Douglas M. 2019. The Merchant of Venice. Language E Writing. London/New York: Bloomsbury, 2019.

LÉVI-STRAUSS, Claude. 1969. The Elementary Structures of Kinship. Boston: Beacon Press, 1969.

MARSDEN, Jean I. 1995. The Re-Imagined Text. Shakespeare, Adaptation, E Eighteenth-Century Literary Theory. Lexington: The University Press of Kentucky, 1995.

MURRAY, Barbara. 2012. 'Strange Star': Same-Sex Love and William Burnaby's Love Betray'd or The Agreeable Disapointment (1703). English Studies 93 (2012): 2: 177-187.

NEWMAN, Karen. 1987. Portia's Ring: Unruly Women and Structures of Exchange in The Merchant of Venice. Shakespeare Quarterly 38 (1987): 1: 19-33.

PATTERSON, Steve. 1999. The Bankruptcy of Homoerotic Amity in Shakespeare's Merchant of Venice. Shakespeare Quarterly 50 (1999): 1: 9-32.

ROWE, Nicholas. 1709. The works of Mr. William Shakespear in Six Volumes. London: Printed for Jacob Tonson, 1709. 
SCHNEIDER, Ben Ross. 1993. Granville's Jew of Venice (1701): A Close Reading of Shakespeare's Merchant. Restoration: Studies in English Literary Culture, 1660-1700 17 (1993): 2: 111134.

SEDGWICK Kosofsky, Eve. 1985. Between Men: English Literature and Male Homosocial Desire. New York: Columbia University Press, 1985.

SHAKESPEARE, William. 2010. The Merchant of Venice. John Drakakis (ed.). London/New York: Bloomsbury, 2010.

SINFIELD, Alan. 1996. How to read The Merchant of Venice without being heterosexist. In Terence Hawkes (ed.). Alternative Shakespeares 2. London/New York: Routledge, 1996: 123-139.

STAVES, Susan. 1990. Married Women's Separate Property in England, 1660-1833. Cambridge, MA/London: Harvard University Press, 1990.

WILSON, Harold J. 1943. Granville’s ‘Stock-Jobbing Jew’. Philological Quarterly 13 (1943): 1: 1-15. ZACCHI, Romana. 1994. The Jew of Venice di George Granville. In Mariangela Tempera (ed.). The Merchant of Venice dal testo alla scena. Bologna: Clueb, 1994, 197-211.

ZEMON DAVIS, Natalie. 1975. Society and Culture in Early Modern France. Stanford: Stanford University Press, 1975. 


\section{Prof. Lisanna Calvi}

Department of Foreign Languages and Literatures,

University of Verona, Lungadige Porta Vittoria 41, 37129 Verona, Italy

lisanna.calvi@univr.it

Lisanna Calvi is Associate Professor of English Literature at the University of Verona. Her main research interests have focussed on Restoration and early modern drama and literary culture. She has written a book on Restoration and early eighteenth-century tragedy (QuiEdit, 2015) and on James II's devotional papers and Imago Regis (ETS, 2009). She also authored articles on John Dryden (2000), Robert Browning (2002, 2010), Thomas Otway (2007), Edmund Gosse (2009), The Tempest and the commedia dell'arte (Routledge, 2012), madness and autobiography in seventeenth-century England (2012 and 2013), Romeo and Juliet on the nineteenth-century Italian stage (2013 and 2017), and Shakespearean eighteenth-century adaptation (2020). She co-edited a miscellany on The Tempest (Palgrave, 2014) and on Romeo and Juliet (Routledge, 2016). She has recently edited a collection on Romeo and Juliet and its afterlife (ETS, 2018). She is currently working on a project on Italian nineteenth-century Shakespearean actors with a focus on Romeo and Juliet. 